\title{
Fertilization Effects on the Phosphorus Content of Browse Species
}

\section{J.H. EVERITT AND H.W. GAUSMAN}

\begin{abstract}
A study was conducted in Hidalgo County, southern Texas, to determine the effects of inorganic nitrogen (N) and phosphorus (P) fertilization on the $P$ content of 5 deer browse species. Treatments were 2 rates of $N-112$ and $224 \mathrm{~kg} N /$ ha; 2 rates of $P-56$ and $112 \mathrm{~kg}$ $\mathrm{P} / \mathrm{ha}$; 1 fertilizer combination of $224 \mathrm{~kg} \mathrm{~N} / \mathrm{ha}+112 \mathrm{~kg} \mathrm{P} / \mathrm{ha}$; and a nonfertilized control. Plant samples were collected and assayed for P on 5 dates: May, September, and December 1981, and May and October 1982. Neither $P$ or $N$ fertilization influenced $P$ browse content. Results indicated that $\mathbf{P}$ deficiencies in the browse plant species studied could not be alleviated by $P$ fertilization.
\end{abstract}

Few studies have been conducted on the effects of fertilizers on the nutritional quality of browse plants. Gibbens and Pieper (1962) reported increased levels of crude protein (CP) in the leaves of wedgeleaf ceanothus (Ceanothus cuneatus Torr. \& Gray) after nitrogen $(N)$ fertilization on a California range. Similar results have been reported of other browse plant species in Pennsylvania, Maine, and New Mexico studies (Wood and Lindsey 1967, Abel and Gilbert 1974, Anderson et al. 1974).

Recently, Everitt and Gausman (1983) reported on the influence of $\mathbf{N}$ fertilization on the chemical composition of south Texas deer browse plants. They found that $\mathrm{N}$ fertilization increased the $\mathrm{CP}$ content of the browse plants, but had little influence on their mineral ( $\mathrm{P}, \mathrm{Ca}, \mathrm{K}$, and $\mathbf{M g}$ ) composition. Phosphorus levels in south Texas browse plants are generally below the dietary requirements of deer (Varner et al. 1977, Everitt and Gonzalez 1981). The purpose of this study was to determine the influence of $\mathrm{N}$ and $\mathrm{P}$ fertilizer and their interactions on the $\mathrm{P}$ content of 5 woody plants species important as browse for white-tailed deer (Odocoileus virginianus Boddaert) in south Texas.

\section{Materials and Methods}

The study was conducted in 1981 and 1982 on the H. Yturria La Joya Lake Ranch, $\mathbf{4} \mathrm{km}$ northwest of La Joya in Hidalgo County, Texas, which is located in the extreme southern portion of the South Texas Plains (Gould 1975). The climate, topography, and vegetation of this area have been described (Everitt and Gonzalez 1979 , Jacobs 1981). The study area received above-normal rainfall during 1981 and for the first 5 months of 1982. Mean annual precipitation for the area is $51 \mathrm{~cm}$, but during 1981 rainfall totaled $88.9 \mathrm{~cm}$ ( $74 \%$ above normal). Rainfall was also evenly distributed during 1981 with substantial rainfall during late winter and spring following fertilization. From January-May 1982, the area received $26 \mathrm{~cm}$ of rainfall (46\% above normal). However, only $8.1 \mathrm{~cm}$ of rainfall ( $63 \%$ below normal) was recorded during the last 5 months (June-October 1982) of the study.

The experiment was located on a sandy loam range site with Brennan fine sandy loam soil (Aridic Haplustalfs). Brush on the site was bulldozed in 1979, but was reinfesting the area when this study was conducted. Brush regrowth was generally less than $1 \mathrm{~m}$ in height. The area had approximately $5 \%$ woody canopy cover. The experimental design was a randomized complete block with 3 replications of 6 fertility treatments. Treatments were 2 rates of $\mathbf{N}$

\footnotetext{
Authors are range scientist and supervisory plant physiologist, respectively, USDA, ARS, Weslaco, Texas 78596; USDA, ARS, Texas Tech University, Plant Stress and Water Conservation Research Unit, Lubbock, Texas 79409.

The authors wish to thank the H. Yturria Ranch personnel for their cooperation and M.A. Alaniz for his field and laboratory assistance.

Manuscript accepted 12 September 1985.
}

(ammonium sulfate)-112 and $224 \mathrm{~kg} \mathrm{~N} / \mathrm{ha} ; 2$ rates of $\mathrm{P}\left(\mathrm{P}_{2} \mathrm{O}_{5}\right)$ 56 and $112 \mathrm{~kg} \mathrm{P} / \mathrm{ha} ; 1$ combination of $224 \mathrm{~kg} \mathrm{~N} / \mathrm{ha}+112 \mathrm{~kg} \mathrm{P} / \mathrm{ha}$; and a control (nonfertilized). Plot size was $6.1 \times 107.7 \mathrm{~m}$. All fertilizers were applied in late February 1981 with a rotary fertilizer distributor. The study area was enclosed by an electric fence to exclude cattle.

Soil samples were taken in January 1981, prior to applying fertilizer, with a hydraulic soil-core machine. Cores were taken from 8 random locations throughout the area, and divided into 2 increments based on depth: $0-30$ and $30-60 \mathrm{~cm}$. These soil samples were analyzed for nitrate-nitrogen $\left(\mathrm{NO}_{3}-\mathrm{N}\right)$, available $\mathrm{P}$, and $\mathrm{pH}$ by the Texas Agricultural Extension Soil Testing Laboratory (TAESTL 1980).

Five browse species were selected for nutrient analyses: cenizo (Leucophyllum frutescens (Berl.) I.M. Johnst.), desert lantana (Lantana macropoda Torr.), granjeno (Celtis pallida Torr.), guayacan (Porlieria angustifolia (Engelm.) Gray), and lime pricklyash (Zanthoxylum fagara (L.) Sarg.). The 5 species, which were abundant on the experimental site, were selected because they are important foods of the white-tailed deer in south Texas (Everitt and Drawe 1974, Everitt and Gonzalez 1979, Arnold and Drawe 1979). Plant samples were collected for chemical analyses on 5 dates: 27 May, 10 Sept., and 10 Dec. 1981, and 25 May and 29 Oct., 1982. Plant samples were collected, processed for analysis, and analyzed for $\mathbf{P}$ according to procedures of Everitt and Gausman (1983).

Data were subjected to analysis of variance (Steel and Torrie 1960). F-ratios were calculated for the main effects of treatments and species, and the treatment $X$ species interaction. Duncan's multiple range test was used to test the statistical significance of mean differences. All statistical comparisons were made at the $0.05 \%$ probability level.

\section{Results and Discussion}

Soil tests in January 1981 indicated that there was moderately low $\mathrm{P}$ and low $\mathrm{NO}_{-}-\mathrm{N}$ levels throughout the study area. For the upper $60 \mathrm{~cm}$ of soil, the average $P$ level was less than $14 \mathrm{ppm}$, while the $\mathrm{NO}_{3}-\mathrm{N}$ level was $5 \mathrm{ppm}$. The soil had a $\mathrm{pH}$ of 8.5 These tests indicated that there should be a plant response to $\mathbf{P}$ and $\mathbf{N}$ fertilization.

Fertilization with $N, P$, and $N$ with $P$ had no affect on the browse plants' $P$ content on any of the 5 harvest dates (Table 1). Further, there were no statistically significant treatment $X$ species interactions on any of the sampling dates. Phosphorus levels, however, did differ significantly among the 5 species on all sampling dates. Desert lantana had higher and guayacan had lower levels of $P$ than did the other species. The failure of $\mathbf{N}$ fertilization to affect the $P$ content of the browse plants agrees closely with the findings of the browse fertilization study of Everitt and Gausman (1983), which was conducted on a tight sandy loam range site. Apparently, similar results occur on the lighter textured sandy loam range sites. Moreover, the current study indicated that $P$ deficiencies in these 5 browse species cannot be corrected by adding $\mathrm{P}$ fertilizer. Although soil $P$ levels were not extremely low, they were low enough to expect a response to $\mathbf{P}$ fertilization. Possibly the moderately high alkalinity of the soil could have caused the $P$ to become fixed in the soil and thus unavailable for plant utilization. 
Table 1. Phosphorus content of five south Texas browse species following nitrogen and phosphorus fertilization.

\begin{tabular}{|c|c|c|c|c|c|c|c|}
\hline \multirow[b]{2}{*}{ Date and species } & \multicolumn{6}{|c|}{ Treatments (kg/ha) } & \multirow[b]{2}{*}{ Species means } \\
\hline & Control & $112 \mathrm{~N}$ & $224 N$ & $56 \mathrm{P}$ & $112 \mathrm{P}$ & $224 \mathrm{~N}+112 \mathrm{P}$ & \\
\hline \multicolumn{8}{|l|}{ May 1981} \\
\hline $\begin{array}{l}\text { Cenizo } \\
\text { Desert lantana } \\
\text { Granjeno } \\
\text { Guayacan } \\
\text { Lime pricklyash }\end{array}$ & $\begin{array}{l}0.19 \\
0.30 \\
0.25 \\
0.13 \\
0.23\end{array}$ & $\begin{array}{l}0.20 \\
0.29 \\
0.26 \\
0.12 \\
0.23\end{array}$ & $\begin{array}{l}0.20 \\
0.31 \\
0.25 \\
0.13 \\
0.22\end{array}$ & $\begin{array}{l}0.20 \\
0.31 \\
0.27 \\
0.15 \\
0.25\end{array}$ & $\begin{array}{l}0.19 \\
0.30 \\
0.27 \\
0.12 \\
0.22\end{array}$ & $\begin{array}{l}0.21 \\
0.32 \\
0.26 \\
0.12 \\
0.22\end{array}$ & $\begin{array}{l}0.20 \mathrm{~d} \\
0.31 \mathrm{a} \\
0.26 \mathrm{~b} \\
0.13 \mathrm{e} \\
0.23 \mathrm{c}\end{array}$ \\
\hline Treatment means & $0.22 \mathrm{a}$ & $0.22 \mathrm{a}$ & $0.22 \mathrm{a}$ & $0.24 \mathrm{a}$ & $0.22 \mathrm{a}$ & $0.23 \mathrm{a}$ & \\
\hline $\begin{array}{l}\text { Sep. } 1981 \\
\text { Cenizo } \\
\text { Desert lantana } \\
\text { Granjeno } \\
\text { Guayacan } \\
\text { Lime pricklyash }\end{array}$ & $\begin{array}{l}0.26 \\
0.35 \\
0.34 \\
0.10 \\
0.28\end{array}$ & $\begin{array}{l}0.26 \\
0.35 \\
0.33 \\
0.12 \\
0.26\end{array}$ & $\begin{array}{l}0.26 \\
0.38 \\
0.30 \\
0.14 \\
0.29\end{array}$ & $\begin{array}{l}0.26 \\
0.37 \\
0.31 \\
0.15 \\
0.27\end{array}$ & $\begin{array}{l}0.25 \\
0.34 \\
0.34 \\
0.13 \\
0.27\end{array}$ & $\begin{array}{l}0.28 \\
0.38 \\
0.31 \\
0.13 \\
0.28\end{array}$ & $\begin{array}{l}0.26 \mathrm{c} \\
0.36 \mathrm{a} \\
0.32 \mathrm{~b} \\
0.13 \mathrm{~d} \\
0.28 \mathrm{c}\end{array}$ \\
\hline Treatment means & $0.27 \mathrm{a}$ & $0.26 \mathrm{a}$ & $0.27 \mathrm{a}$ & $0.27 \mathrm{a}$ & $0.27 \mathrm{a}$ & $0.28 \mathrm{a}$ & \\
\hline $\begin{array}{l}\text { Dec. } 1981 \\
\text { Cenizo } \\
\text { Desert lantana } \\
\text { Granjeno } \\
\text { Guayacan } \\
\text { Lime pricklyash }\end{array}$ & $\begin{array}{l}0.11 \\
0.19 \\
0.15 \\
0.12 \\
0.14\end{array}$ & $\begin{array}{l}0.13 \\
0.19 \\
0.14 \\
0.11 \\
0.15\end{array}$ & $\begin{array}{l}0.17 \\
0.20 \\
0.13 \\
0.11 \\
0.16\end{array}$ & $\begin{array}{l}0.14 \\
0.19 \\
0.13 \\
0.10 \\
0.17\end{array}$ & $\begin{array}{l}0.14 \\
0.17 \\
0.14 \\
0.09 \\
0.16\end{array}$ & $\begin{array}{l}0.16 \\
0.21 \\
0.14 \\
0.10 \\
0.17\end{array}$ & $\begin{array}{l}0.14 \mathrm{c} \\
0.19 \mathrm{a} \\
0.14 \mathrm{c} \\
0.11 \mathrm{~d} \\
0.16 \mathrm{~b}\end{array}$ \\
\hline Treatment means & $0.14 \mathrm{a}$ & $0.14 \mathrm{a}$ & $0.15 \mathrm{a}$ & $0.15 \mathrm{a}$ & $0.14 \mathrm{a}$ & $0.16 \mathrm{a}$ & \\
\hline $\begin{array}{l}\text { May } 1982 \\
\text { Cenizo } \\
\text { Desert lantana } \\
\text { Granjeno } \\
\text { Guayacan } \\
\text { Lime pricklyash }\end{array}$ & $\begin{array}{l}0.21 \\
0.30 \\
0.22 \\
0.11 \\
0.22\end{array}$ & $\begin{array}{l}0.20 \\
0.28 \\
0.22 \\
0.10 \\
0.20\end{array}$ & $\begin{array}{l}0.22 \\
0.31 \\
0.21 \\
0.10 \\
0.20\end{array}$ & $\begin{array}{l}0.22 \\
0.31 \\
0.22 \\
0.10 \\
0.20\end{array}$ & $\begin{array}{l}0.21 \\
0.27 \\
0.21 \\
0.11 \\
0.21\end{array}$ & $\begin{array}{l}0.22 \\
0.31 \\
0.22 \\
0.10 \\
0.21\end{array}$ & $\begin{array}{l}0.21 \mathrm{~b} \\
0.30 \mathrm{a} \\
0.22 \mathrm{~b} \\
0.10 \mathrm{c} \\
0.21 \mathrm{~b}\end{array}$ \\
\hline Treatment means & $0.21 \mathrm{a}$ & $0.20 \mathrm{a}$ & $0.21 \mathrm{a}$ & $0.21 \mathrm{a}$ & $0.20 \mathrm{a}$ & $0.21 \mathrm{a}$ & \\
\hline $\begin{array}{l}\text { Oct. } 1982 \\
\text { Cenizo } \\
\text { Desert lantana } \\
\text { Granjeno } \\
\text { Guayacan } \\
\text { Lime pricklyash }\end{array}$ & $\begin{array}{l}0.18 \\
0.27 \\
0.20 \\
0.07 \\
0.24\end{array}$ & $\begin{array}{l}0.19 \\
0.28 \\
0.20 \\
0.08 \\
0.21\end{array}$ & $\begin{array}{l}0.19 \\
0.29 \\
0.19 \\
0.07 \\
0.25\end{array}$ & $\begin{array}{l}0.16 \\
0.29 \\
0.20 \\
0.08 \\
0.29\end{array}$ & $\begin{array}{l}0.17 \\
0.27 \\
0.20 \\
0.05 \\
0.23\end{array}$ & $\begin{array}{l}0.18 \\
0.30 \\
0.20 \\
0.08 \\
0.27\end{array}$ & $\begin{array}{l}0.18 \mathrm{~d} \\
0.28 \mathrm{a} \\
0.20 \mathrm{c} \\
0.07 \mathrm{e} \\
0.25 \mathrm{~b}\end{array}$ \\
\hline Treatment means & $0.19 \mathrm{a}$ & $0.19 \mathrm{a}$ & $0.20 \mathrm{a}$ & $0.20 \mathrm{a}$ & $0.18 \mathrm{a}$ & $0.21 \mathrm{a}$ & \\
\hline
\end{tabular}

'Means followed by the same letter within a column or row do not differ significantly at the $0.05 \%$ probability level, according to Duncan's multiple range test.

\section{Literature Cited}

Abel, D.H., and F.F. Gilbert. 1974. Nutrient content of fertilized deer browse in Maine. J. Wildl. Manage. 38:517-524.

Anderson, B.L., R.D. Pieper, and V.H. Howard, Jr. 1974. Growth response and deer utilization of fertilized browse. J. Wildl. Manage. 38:525-530.

Arnold, L.A., Jr., and D.L. Drawe. 1979. Seasonal food habits of whitetailed deer in the South Texas Plains. J. Range Manage. 32:175-178.

Everitt, J.H., and D.L. Drawe. 1974. Spring food habits of white-tailed deer in the South Texas Plains. J. Range Manage. 27:15-20.

Everitt, J.H., and H.W. Gausman. 1983. Seasonal effects of nitrogen fertilization on three species of south Texas browse plants. J. Range Manage. 36:662-664.

Everitt, J.H., and C.L. Gonzalez. 1979. Botanical composition and nutrient content of fall and early winter diets of white-tailed deer in south Texas. Southwestern Natur. 24:297-310.

Everitt, J.H., and C.L. Gonzalez. 1981. Seasonal nutrient content in food plants of white-tailed deer on the South Texas Plains. J. Range Manage. 34:506-510.
Gibbens, R.P., and R.D. Pieper. 1962. The response of browse plants to fertilization. California Fish and Game. 48:268-281.

Gould, F.W. 1975. Texas plants-A checklist and ecological summary. Texas Agr. Exp. Sta. MP-585.

Jacobs, J.L. 1981. Soil survey of Hidalgo County, Texas. USDA, Soil Conservation Service. U.S. Government Printing Office, Washington, D.C.

Steel, R.G.D., and J.H. Torrie. 1960. Principles and procedures of statistics. McGraw-Hill, New York.

Texas Agricultural Extension Soll Testing Laboratory. 1980. Soil testing procedures. Texas Agricultural Extension Service. College Station, Texas.

Varner, L.W., L.H. Blankenship, and G.W. Lynch. 1977. Sesonal changes in nutritive value of deer food plants in south Texas. Proc. Annual Conf. S.E. Ass. Fish and Wildlife Agencies. 31:99-106.

Wood, G.W., and J.S. Linsey. 1967. The effect of forest fertilization on the crude protein, calcium, and phosphorus content of deer browse in a mixed oak forest. Pennsylvania Coop. Wildl. Res. Pap. 126. 